\title{
A RARE CASE OF INFECTIOUS MULTIFOCAL SERPIGINOID CHOROIDITIS
}

\author{
Miloš Mitrašević ${ }^{1}$, Svetlana Jovanović ${ }^{2}$, Filip Radotić ${ }^{3}$, Snežana Pešić ${ }^{3}$ and Zorica Jovanović ${ }^{4}$ \\ ${ }^{1}$ Department of Hospital Healthcare, ${ }^{2}$ Clinical Department of Ophthalmology, Faculty of Medical Sciences; \\ ${ }^{3}$ Faculty of Medical Sciences; ${ }^{4}$ Department of Pathophysiology, Faculty of Medical Sciences, \\ University of Kragujevac, Kragujevac, Serbia
}

\begin{abstract}
SUMMARY - Multifocal serpiginoid choroiditis is an infectious variety of serpiginous choroiditis. The disease is characterized by infectious etiology and overlapping clinical features in an intermediary form of acute posterior multifocal placoid pigment epitheliopathy and serpiginous choroiditis. In a 33-year-old patient, bilateral multiple placoid partially confluent chorioretinal lesions were diagnosed after a febrile flu-like episode. On the right eye, there was a progressive decrease in visual acuity. Later, the lesions had a prolonged progressive devastating clinical course and widespread distribution of placoid lesions, and took the form of serpiginoid choroiditis. We conducted extensive laboratory work-up and ancillary investigation for granulomatous diseases such as tuberculosis and sarcoidosis, and the results were not consistent with these entities. Systemic medical work-up revealed a history of exposure to the human immunodeficiency virus, herpes simplex virus 1, varicella zoster virus and cytomegalovirus. The titer of Mycoplasma pneumoniae IgM antibodies was positive. After serological analysis positive for Mycoplasma pneumoniae, systemic antibiotic therapy and anti-inflammatory doses of corticosteroids were administered. Improvement of visual acuity after the introduction of causal antibiotic therapy in combination with anti-inflammatory therapy confirmed our suspicion that $M y$ coplasma pneumoniae was the etiologic cause of multifocal serpiginoid choroiditis.
\end{abstract}

Key words: Acute posterior multifocal placoid pigment epitheliopathy; Serpiginoid choroiditis; Serpiginous choroiditis; Mycoplasma pneumoniae

\section{Introduction}

Multifocal serpiginoid choroiditis (MSC) is an uncommon clinical entity from the group of infectious choroiditis, which is characterized by sectoral nonperfusion of choriocapillaris with subsequent ischemia and dysfunction of retinal pigment epithelium and photoreceptor cells of the outer retina ${ }^{1,2}$. The etiopathogenic mechanism of serpiginous choroiditis is autoimmune ${ }^{3}$, infectious ${ }^{4}$, vascular and degenerative ${ }^{5}$. The term multifocal serpiginoid choroiditis has been suggested for the infective variant of serpiginous choroiditis ${ }^{5-7}$. Serpiginous choroiditis is used to describe a

Correspondence to: Svetlana V. Jovanovic, MD, PhD, PO Box 109, 34000 Kragujevac, Serbia

E-mail: drsvetlanajovanovic@yahoo.com

Received January 28, 2016, accepted September 26, 2016 chronic recurrent geographic pattern of choroiditis that typically extends from the peripapillary area. The infectious type of serpiginous choroiditis is commonly associated with tuberculosis ${ }^{5-9}$. Isolated cases are associated with Lyme borreliosis ${ }^{3}$, Epstein-Barr virus ${ }^{4}$, herpes simplex virus 1 , varicella zoster virus, cytomegalovirus, and toxoplasma ${ }^{4,6,7}$. Biochemical and serological examinations, multimodal imaging ${ }^{8}$ and functional parameters facilitate diagnosis and management $^{4,9}$. Clinical differences within choroidopathies could possibly be explained by the level and severity of the inflammatory insult to the choriocapillaris circulation, the consequent damage to the retinal pigment epithelium and photoreceptor cells, and the moderate diffuse lymphocytic infiltrates throughout the choroid $^{2}$. Therapy should be adjusted to the course of inflammatory diseases because we know the structures 
that are primarily affected, and in some cases the etiology is also known. Treatment includes patient monitoring, specific anti-infectious therapy, with or without corticosteroid anti-inflammatory effects ${ }^{6,7,10}$. In case of the development of neovascular membranes, photodynamic and anti-angiogenic therapy should be considered $^{11-13}$

The aim is to present a case study considering this specific pathology, i.e. the devastating course of a case of infectious MSC from the group of infectious serpiginous choroiditis. The study protocol was approved by the institutional review boards and adhered to the tenets of the Declaration of Helsinki.

\section{Case Report}

A 33-year-old man presented to Clinical Department of Ophthalmology, Kragujevac Clinical Center, with the symptoms of photopsia and decreased visual acuity of 0.05 on the right eye and 1.0 on the left eye (Snellen charts), which developed after a febrile flulike episode. Intraocular pressure was $14 \mathrm{~mm} \mathrm{Hg}$ on both eyes. Biomicroscopy revealed no exudation in the anterior segment and anterior vitreous of either eye. Funduscopic examination detected numerous creamywhite lesions of the retina over the inflamed area of the choriocapillaris ischemia. The lesions were present in the mid-periphery bilaterally and at the posterior pole of the right eye (Fig. 1 a, b). Bilateral lesions are aspects of acute posterior multifocal placoid pigment epitheliopathy (APMPPE) with progressive evolution in serpiginous choroiditis, probably of infectious etiology. Choroiditis has a prolonged, devastating clinical course and widespread distribution of lesions, and takes the form of serpiginoid choroiditis. Perimeter examination detected an absolute absence of sensitivity in the right eye, and objective paracentral scotomata and reduced sensitivity in the left eye. Color vision (Ishihara test) was preserved in the left eye. Fluorescein angiography of the right fundus showed distribution of field hypofluorescence that induced choriocapillaris nonperfusion (early stage), as well as progressive late staining, a pattern compatible with ischemic dysfunction of the outer retina (late phase) (Fig. 2a); similar changes also prevailed in the fundus of the left eye (Fig. 2b). Heidelberg retina tomography showed retina without structural changes in both eyes. Visual evoked potentials showed the left eye with proper cortical re-

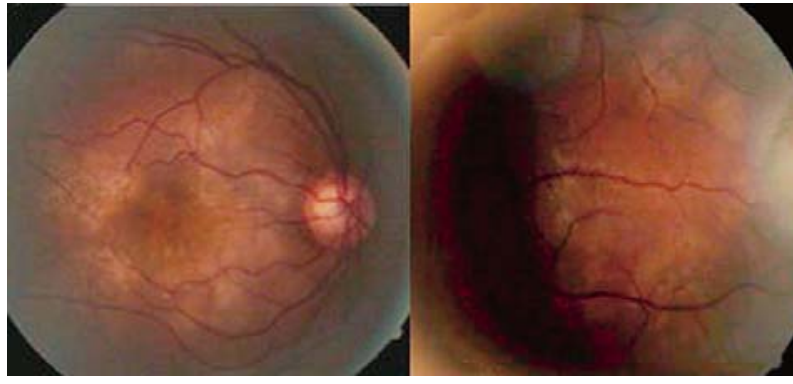

Fig. 1. A 33-year-old man with bilateral active multifocal serpiginoid choroiditis lesions $(a, b)$ : color fundus image of the right eye showing multiple creamywhite lesions inflamed above the choriocapillaris ischemic zone, localized in the posterior pole (a), with progression of the very same lesions detected at the mid-peripheral site in the left eye.

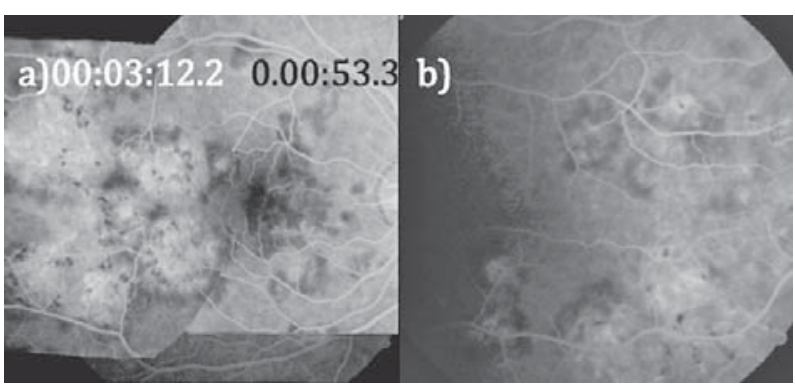

Fig. 2. (a) Fluorescein angiography of the right eye fundus showing distribution areas of the bypofluorescence that indicate choriocapillaris nonperfusion (early stage), as well as progressive and easy hypofluorescence of multiple areas of confluent pattern (late phase) at the upper periphery posterior pole, capturing the macula, only 3 days after hospitalization of this 33-year-old male; (b) the same changes prevailing in the left eye fundus.

sponse, while the right cortical response was not generated. Optical coherence tomography revealed macular atrophy of the right eye, and retinal pigment epithelium thickness and mild detachment in the macula of the left eye. The patient underwent extensive laboratory testing and ancillary investigation for granulomatous diseases such as tuberculosis (tuberculin skin test, interferon $\gamma$ release assay, and sputum for Mycobacterium tuberculosis on Löwenstein medium), sarcoidosis ${ }^{14}$ (angiotensin converting enzyme, chest x-ray and computed tomography of the mediastinum), and none was consistent with these entities. A systemic medical work-up revealed a history of exposure to human immunodeficiency virus (antiHIV IgG titer >1:320; IgM 
titer <1:16), herpes simplex (antiherpes simplex IgG titer >1:320; IgM titer <1:16), varicella zoster virus (antivaricella zoster virus IgG titer $>1: 320$; IgM titer $<1: 16$ ), cytomegalovirus (anticytomegalovirus IgG titer $>1: 320$; IgM titer $<1: 16$ ) and toxoplasmosis (antitoxoplasma IgG titer $<1: 16$; IgM titer $<1: 16)$. The titer of Mycoplasma pneumoniae IgM was positive (1:640). ELISA complemented by the Western blot test did not detect IgM antibodies to Borrelia burgdorferi (IgG titer $<1 / 40)$ and Treponema pallidum particle agglutination assay was nonreactive.

During hospitalization, there was progression of the disease with consequent decrease in visual acuity on the left eye to 0.8 according to Snellen. Suspecting MSC after serological analysis positive for Mycoplasma pneumoniae, specific systemic antibiotic therapy with doxycycline $100 \mathrm{mg} 2 \mathrm{x} 1$ for three weeks with anti-inflammatory doses of corticosteroids tapered by a scheme (starting dose of prednisolone $1 \mathrm{mg} / \mathrm{kg}$ body weight) was administered ${ }^{15}$. Following this treatment, the best corrected visual acuity was 1.0 on the left eye, whereas the right eye showed no improvement of visual acuity due to inversion of damage to the macula.

\section{Conclusion}

The characteristic funduscopy finding, the devastating clinical course confirmed by fluorescein angiography, and additional diagnostic tests suggested that MSC was the clinical entity in our patient. The improvement of visual acuity, and reduction of changes following initial causal antibiotic therapy combined with anti-inflammatory doses of corticosteroids confirmed our suspicion that Mycoplasma pneumoniae was the causative agent in this case of MSC.

\section{References}

1. Herbort CP. Choroiditis: general considerations and classification. In: Pleyer U, Mondino B, editors. Essentials in Ophthalmology: Uveitis and Immunological Disorders. $1^{\text {st }}$ edn. Berlin, Heidelberg, New York: Springer; 2004. pp. 202-8. doi: 10.1007/3-540-26752-2_13

2. Lim Wk, Buggage RR, Nussenblatt RB. Serpiginous choroiditis. Surv Ophthalmol. 2005;50(3):231-44. http://dx.doi.org10. 1016/j.survophthal.2005.02.010
3. Erkkila H, Laatikainen L, Jokinen E. Immunological studies on serpiginous choroiditis. Graefes Arch Clin Exp Ophthalmol. 1982;219:131-4. PMID: 6757060

4. Gupta V, Gupta A, Rao NA. Intraocular tuberculosis - an update. Surv Ophthalmol. 2007;52:561-87. http://dx.doi.org 10.1016/j.survophthal.2007.08.015

5. Shetty Sachin B, Biswas J, Murali S. Real-time and nested polymerase chain reaction in the diagnosis of multifocal serpiginoid choroiditis caused by Mycobacterium tuberculosis - a case report. J Ophthalmic Inflamm Infect. 2014;4:29. http:// dx.doi.org 10.1186/s12348-014-0029-5

6. Nazari KH, Rao NA. Serpiginous choroiditis and infectious multifocal serpiginoid choroiditis. Surv Ophthalmol. 2013;58: 203-32. http://dx.doi.org 10.1016/j.survophthal.2012.08.008

7. Vasconcelos-Santos DV, Rao PK, Davies JB, Sohn EH, Rao NA. Clinical features of tuberculous serpiginous-like choroiditis in contrast to classic serpiginous choroiditis. Arch Ophthalmol. 2010;128(7):853-8. http://dx.doi.org 10.1001/archophthalmol.2010.116

8. Kuznetcova T, Jeannin B, Herbort CP. A case of overlapping choriocapillaritis syndromes: multimodal imaging appraisal. J Ophthalmic Vis Res. 2012;7(1):67-75. https://www.ncbi.nim. nih.gov/pms/article/PMC3381111

9. De Luigi G, Mantovani A, Papadia M, Herbort CP. Tuberculosis-related choriocapillaritis (multifocal-serpiginous choroiditis): follow-up and precise monitoring of therapy by indocyanine green angiography. Int Ophthalmol. 2012;2(1):55-60. http://dx.doi.org10.1007/s10792-011-9508-y

10. Mohan N, Balne PK, Panda KG, Sharma S, Basy S. Polymerase chain reaction evaluation of infectious multifocal serpiginoid choroiditis. Ocul Immunol Inflamm. 2014;22(5):384-40. http://dx.doi.org0.3109/09273948.2014.907433

11. Jones BE, Jampol LM, Yannuzzi LA, Tittl M, Johnson MW, Han DP, Davies JB, et al. Relentless placoid chorioretinitis - a new entity or an unusual variant of serpiginous chorioretinitis? Arch Ophthalmol. 2000;118(7):931-8. http://dx.doi.org101001/pubs.Ophthalmol.-ISSN-0003-9950-118-7-ecs80142

12. Alok A, Jyotirmay B, Samanthila W. Serpiginous choroiditis: an update. Asia Pacific Biotech News. 2012;16(1)30-40.

13. Perentes Y, Van Tran T, Sickenberg M, Herbot CP. Subretinal neovascular membranes complicating uveitis frequency, treatments and visual outcome. Ocul Immunol Inflamm. 2005;13 (2-3):219-24. http://dx.doi.org10.1080/09273940490518883

14. Jovanović SV, Jovanović ZD, Radotić FM, Srećković SB, Paunović SS, Stojanović JD. Clinical aspects of posterior uveitis in ocular sarcoidosis. Acta Clin Croat. 2012;51(2):247-53. http://hrcak.srce.hr/106549 PMID: 23115950

15. Gašparić M, Penezić A, Kolumbić-Lakoš A, Kovačić D, Kukuruzović MM, Baršić B. Safety and effectiveness of azithromycin in the treatment of lower respiratory infections: an international, multicenter, non-comparative study. Acta Clin Croat. 2015;54(2):149-58. PMID: 26489107 


\section{Sažetak}

\section{RIJEDAK SLUČAJ MULTIFOKALNOG SERPIGINOIDNOG KOROIDITISA}

\section{Mitrašević, S. Jovanović, F. Radotić, S. Pešić i Z. Jovanović}

Multifokalni serpiginoidni koroiditis je infektivna varijanta serpiginoznog koroiditisa. Bolest obilježava infektivna etiologija i preklapanje kliničke slike između akutnog oblika stražnje multifokalne plakoidne pigmentne epiteliopatije i serpiginoznog koroiditisa. Nakon epizode poput febrilne gripe bolesniku u dobi od 33 godine dijagnosticirane su bilateralne, brojne, plakoidne, djelomice konfluentne korioretinalne lezije. Na desnom oku vidna oštrina se progresivno smanjivala. Kasnije su lezije poprimile prolongirani, progresivni, razarajući klinički tijek i raširenu distribuciju plakoidnih lezija u obliku serpiginoidnog koroiditisa. Proveli smo opsežne laboratorijske testove i pomoćnu dijagnostiku za granulomatozne bolesti poput tuberkuloze i sarkoidoze, ali rezultati nisu potvrdili uzročnika. Daljnja sistemska medicinska obrada je pokazala povijest izlaganja virusu humane imunodeficijencije, herpes simpleksu, varičela zoster virusu i citomegalovirusu. Povišen je bio titar IgM antitijela na Mycoplasma pneumoniae. Nakon pozitivnih seroloških analiza na Mycoplasma pneumoniae primijenjena je sistemska antibiotska terapija i protuupalna doza kortikosteroida. Poboljšanje vidne oštrine nakon uvođenja uzročne antibiotske terapije u kombinaciji s protuupalnom terapijom potvrdilo je našu sumnju da je Mycoplasma pneumoniae bila etiološki uzročnik multifokalnog serpiginoidnog koroiditisa.

Ključne riječi: Akutna stražnja multifokalna plakoidna pigmentna epiteliopatija; Serpiginoidni koroiditis; Serpiginozni koroiditis; Mycoplasma pneumoniae 